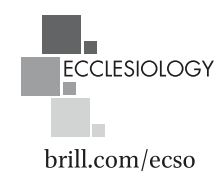

\title{
Editorial
}

\section{The Roles of the Ecclesial Orders in the Governance of the Church}

\author{
Paul Avis \\ Editor-in-Chief of Ecclesiology; Honorary Research Fellow, Department \\ of Theology and Religion, University of Exeter, Exeter, UK \\ dr.paul.avis@gmail.com
}

This Editorial reflects ecclesiologically on the place and role of the ecclesial orders in the governance of the church. By 'the ecclesial orders' I mean the variegated vocational structure of the baptized people of God. I take these orders to be fourfold: bishops, presbyters, deacons and lay people. That list is not in order of theological importance! A moment's reflection teaches us that there can be no hierarchy of callings in the body of Christ. All the baptized are level in status before God, having a full and equal standing in Christ; all are called to discipleship and service. The prestige that accrues to the office of say archbishop, but not to the office of lay minister of communion, is purely a matter of human perception. Even the sacred aura that hovers around certain ministries but not others exists only for human eyes. Bishops and lay people might be thought of as standing at the opposite ends of a spectrum of Christian callings. But this would be an egregious error: there is no such spectrum. Considered biblically and ecclesiologically, the church is a perfectly level playing field.

While lay Christians are of course not in Holy Orders, they are intentionally placed within the overall ordering of the community of the baptized in the service of the missio dei. Laity are just as fully ecclesial persons as the ordained are. Then it is also good to remember that bishops are also priests and deacons and belong to the laos; that presbyters are also deacons and members of the laos; and that deacons remain within the laos too. An order, once bestowed 
by the Holy Spirit through the church, cannot be taken away, but remains as a gift, a calling, and a responsibility. The present short essay deals purely with the ecclesiological and constitutional roles and responsibilities of the four orders, and not with the related, often existentially fraught, matters concerning the practical exercise of power, authority and leadership by those who are entrusted with it, and the issues that arise from the way that they are experienced by those who are on the receiving end of them. ${ }^{1}$ For reasons of space, I am focusing here on the episcopate and the laity.

The issues touched on in this piece are topical and controversial in at least two Christian communions. Both the Roman Catholic Church and the Church of England are currently - though of course separately - engaged in a far-reaching examination of their structures and processes of governance. The Roman Catholic Church, under the leadership of Pope Francis, is seeking to reduce centralization and bureaucracy and instead to enhance the synodical dimension of its governance. It is aiming to do this by broadening consultation and participation, especially by the laity, and at the same time giving greater effect to the proper responsibilities of the episcopate, as affirmed by Vatican II, according to the principle of subsidiarity. ${ }^{2}$ But in apparent contrast to the current moves within the Roman Catholic Church to broaden participation in governance by bishops and laity, a report that is now on the table for the Church of England, while it contains many helpful insights, is clearly intended to reduce elected representation and to narrow participation. If the proposals of the report are fully implemented, the competence and authority of the General Synod and of the House of Bishops within it will be diminished. They will be sacrificed to the enhanced powers of a small central executive. There seems to be a danger here that the voices of the ecclesial orders that make up the church, especially bishops and laity, within the Church of England, will be muted. ${ }^{3}$

\section{Basic Principles of Church Governance}

1 But see Paul Avis, 'Authority and Leadership in the Church (especially diocese and cathedral)', Theology Vol. 123, No. 2 (2020), pp. 113-123; id., Authority, Leadership and Conflict in the Church (London: Mowbray, 1992).

2 International Theological Commission, Synodality in the Life and Mission of the Church $[2$ March 2018], § 35. The document can be found at: https://www.vatican.va/roman_curia/ congregations/cfaith/cti_documents/rc_cti_20180302_sinodalita_en.html. See also the article by Thomas O'Loughlin in this issue.

3 Governance Review Group Report: https://www.churchofengland.org > media/PDF. 
There are some basic principles of church governance that are of wide acceptance. Their premise is that the Lord Jesus Christ is the Head of the Church, which is his Spirit-filled Body (Col. 1:18; 1 Cor. 12:13). It follows that the governance of the church should reflect the twofold truth that Christ is its true Governor and that the whole body is endued with the Holy Spirit to enable it to take collective responsibility for its life, worship and mission. The 'mechanism' for this is 'synodality', historically better known as 'conciliarity'4 Through councils and synods at various levels, the whole church gathers representatively around the open Bible and prays for the guidance of the Holy Spirit. In all churches, to varying degrees and in varying ways, this conciliar or synodical life is founded on certain ecclesiological principles. I would like to explore the meaning of conciliarity by asking a few questions.

(a) Who is responsible for the church: clergy? bishops? popes? Only to some extent. Responsibility for the church ultimately rests with the whole Spirit-bearing body as it participates in Jesus Christ's threefold messianic (anointed) office as our great Prophet, Priest and King. Sharing in his prophetic office, all the baptized are mandated to 'proclaim the mighty acts of him who called you out of darkness into his marvelous light' (1 Pet. 2:9), by living out the gospel in word and deed. Sharing in his priestly office, all Christians persevere in daily prayer, interceding for the needs of the church and the world, and corporately celebrating the Eucharist, with bishop or priest presiding. Sharing in his regal office, the faithful rightfully take their share in the governance of the church. No Christian is called to remain in complete passivity with regard to the church's governance. To deliberately inculcate passivity, docility and unquestioning obedience in clergy and laity goes against the apostolic injunction, 'Quench not the Spirit' (1 Thess. 5:19). So let us next ask:

(b) Who is called to ministry, that is to intentional, acceptable forms of service? Within the church all - whether lay or ordained - are called and commissioned for particular responsibilities and tasks. They are called by the Holy Spirit who also equips them with needful charisms. That calling normally needs to be discerned, recognised and accepted by the church community, at least tacitly, before it can become operative. For public roles, whether lay or ordained, a commissioning is needed; the ordained (deacon, priest, bishop) receive a liturgical, sacramental, commissioning.

4 Francis Oakley, The Conciliarist Tradition: Constitutionalism in the Catholic Church, 1300-1870 (Oxford: Oxford University Press, 2003); Paul Avis, Beyond the Reformation? Authority, Primacy and Unity in the Conciliar Tradition (London and New York: T\&T Clark, 2006). 
But the ordained are not the only ones who are called to ministry, to specific, recognised forms of service.

(c) How does the synodical dimension of the church become a practical reality? Synods need to be convoked or convened. Historically, from the Emperor Constantine onwards, this tended to be done by the civil authority, but in practice today the churches convene their own synods and councils through their highest authority - for the Roman Catholic Church, the Pope; for the Church of England, the Sovereign. The membership of synods is constituted through the representation of various constituencies and interests: ex officio in the case of bishops; by election or appointment in the case of clergy and laity. In episcopally ordered churches, the episcopate has an indispensable role in the conciliar process. Historically, the highest councils ('ecumenical' or 'general' councils) have consisted mainly of bishops, but with non-episcopal advisers (and historically the involvement of the civil authority: prince or emperor). The churches that have been shaped by the Reformation actively involve speaking and voting clergy and laity, as well as bishops or their nearest equivalent, in their synods.

(d) What safeguards are there to prevent the abuse of power in the way that synodality functions? Most basically, synodality needs a constitution or legal, canonical framework in which the scope and limits of the roles and the authority of individuals and groups is laid down (specifying who is entitled to do what). Constitutional principles are the well-winnowed fruit of experience and practice; they cannot be manufactured pragmatically to solve short-term issues. The key principles of conciliarity have evolved over a millennium from their origins in elements of medieval canon law, through the Conciliar Movement that reunited the papacy and the western church in the early fifteenth century, through the liberation of the laity in Reformation theology, to the emergence of representative parliamentary institutions, based on universal adult suffrage, in the early twentieth century.

(e) The four key principles that I draw from the conciliar tradition are as follows. (i) Representation: the effective representation of all groups and interests that have a stake in decision-making must be ensured constitutionally. (ii) Constitutionality: the remit, duties and powers of each part of the governance apparatus are specified. (iii) Consent: the ancient principle that any legal provision whatsoever ultimately finds its validity in the consent of those to whom it applies. The governance of the church is informed by the imperative of consulting the faithful and seeking their consent, through a process of open reception, for decisions that are 
reached. (iv) Expertise: drawing on the best expert and scholarly advice, within but also beyond the categories that are formally represented.

\section{Ordained to Oversight}

Normally a bishop is ordained to a particular diocese or 'portion of the people of God'. A diocesan bishop is entrusted, by ordination and licence, with the exercise of oversight (episkope) in his or her diocese. The Church of England's Canon C 18.4 describe the bishop as 'the principal minister' (i.e. of word and sacrament) within the diocese and the one who celebrates 'the rites of ordination and confirmation' and who oversees the churches and chapels and the church services of parishes within the diocese (except those that are legally exempt), and also institutes to benefices, and licenses clergy for ministry. The bishop carries out all of these tasks, including the ministry of word and sacrament, as the outworking of his or her responsibility for oversight. The responsibility 'to teach and uphold sound and wholesome doctrine, and to banish and drive away all erroneous and strange opinions' and to promote unity, love and peace in the church (C 18.1) also belongs to episcopal oversight. Suffragan and assistant bishops share in the diocesan's oversight by delegation, whether formal through an area scheme or informal. By virtue of their ordination, assisting bishops also share the responsibility for faith and order - to teach and uphold sound doctrine and to promote love, peace and unity in the church, quite apart from the extent of jurisdiction that they receive. Meetings of the whole college of bishops enable suffragans and assistant bishops to participate in this task and to contribute to its accomplishment. They should be appointed with that in mind. All bishops are called to work in a collaborative and collegial way, both with each other and with the clergy and laity of the diocese. Bishops draw the ecclesial orders together to work in a common cause, the cause of the kingdom of Christ. ${ }^{5}$

\section{The Bishop-in-synod}

A bishop's responsibility for oversight is not confined to the bishop's own diocese, but is also exercised in the wider church, again in a corporate and collegial manner. The oft-quoted mantra 'episcopally led and synodically governed'

5 Paul Avis, Becoming a Bishop: A Theological Handbook of Episcopal Ministry (London and New York: T\&T Clark, 2015). 
is woefully inadequate as a summary of the constitution of any church. It is misleading in two ways. (i) Bishops are not the only ones who lead. Lay people also exercise leadership at several levels of the church's life, from the grassroots upwards. (ii) Obviously, bishops, as well as lay people, exercise governance functions. In the diocese they exercise governance in accordance with the canons and other expressions of ecclesiastical law and do so in consultation and conjunction with clergy and laity. In some churches bishops are mainly given a moral and pastoral leadership role, but they should always participate in governance, just as all the faithful do through representation. So the phrase 'the bishop in synod' is more appropriate to describe the role of the episcopate within the polity of the church than the phrase 'episcopally led and synodically governed'. A bishop is always in the midst of his or her people and is called to work actively and cooperatively with them. Every bishop needs to remember that Christ is the great 'shepherd and bishop (episkopos) of [our] souls' and that the faithful whom they oversee on his behalf are his flock, not theirs (1 Pet. 2: 25). Synodical gatherings enable bishops, clergy and laity to consult with each other, according to their particular concerns and perspectives, and to move forward together in shaping policy and practice.

\section{How it Works}

Finally, we need to ask how oversight works and functions in today's cultural climate. (i) It is a given that, by virtue of their ordination and calling, bishops - both individually and collectively - have a special but not exclusive responsibility for the faith and order of the church. This aspect of their oversight centres on the three connected and key areas of doctrine, liturgy and ministry. The special responsibility of the episcopate for these three areas of the church's mission is given minimal credence in the Church of England Governance Review Group Report. (ii) The episcopate (at any level) will fail to carry the church with it if it presents its teachings or rulings in these areas as a fait accompli. It needs the pedagogic arts of informed persuasion to lead the church. If the bishops' proposals meet with widespread resistance, they should undertake further reflection; they have to think again. (iii) Although bishops have a special responsibility for doctrine, worship and ministry by virtue of their order, they alone can not decide, once and for all, any question of doctrine, worship or ministry, nor can they effectively commit the church to their position. The acknowledged faith and order of the church comes about through an extended process of spiritual discernment or reception among the faithful (sensus fidei). (iv) Bishops are in the business of building consensus among clergy and laity 
over time (consensus fidelium), and they do this by example, by convincing teaching and by open dialogue. Such a process brings bishops and lay people together in meaningful interaction.

The same considerations apply to any oversight body, such as the group of a dozen or so 'trustees' that is envisaged in the Governance Review Group Report. High-powered executive groups are helpless unless they enjoy the confidence of the whole body. Institutions can be led but not driven; they can be inspired but not dragooned. The governance and authority structures of most churches have not yet fully taken on board the reality that all churches today function largely as voluntary organisations. Those in any position of leadership need to be acutely aware that people can and frequently do 'vote with their feet'. Maximizing representation, participation and consultation helps people to feel that they are respected and given their due (a definition of basic justice), while also fostering a sense of ownership of initiatives. Continually affirming the virtuous practices of representation, participation and consultation enables leaders to carry their constituency with them - and without that, any purported 'leadership' is a hollow posture. 